\title{
Influence of Compacting Rate on the Properties of Compressed Earth Blocks
}

\author{
Humphrey Danso \\ Department of Construction and Wood Technology, University of Education Winneba, P.O. Box 1277, Kumasi, Ghana \\ Correspondence should be addressed to Humphrey Danso; dansohumphrey@yahoo.co.uk
}

Received 10 June 2016; Accepted 31 August 2016

Academic Editor: Ana S. Guimarães

Copyright (C) 2016 Humphrey Danso. This is an open access article distributed under the Creative Commons Attribution License, which permits unrestricted use, distribution, and reproduction in any medium, provided the original work is properly cited.

\begin{abstract}
Compaction of blocks contributes significantly to the strength properties of compressed earth blocks. This paper investigates the influence of compacting rates on the properties of compressed earth blocks. Experiments were conducted to determine the density, compressive strength, splitting tensile strength, and erosion properties of compressed earth blocks produced with different rates of compacting speed. The study concludes that although the low rate of compaction achieved slightly better performance characteristics, there is no statistically significant difference between the soil blocks produced with low compacting rate and high compacting rate. The study demonstrates that there is not much influence on the properties of compressed earth blocks produced with low and high compacting rates. It was further found that there are strong linear correlations between the compressive strength test and density, and density and the erosion. However, a weak linear correlation was found between tensile strength and compressive strength, and tensile strength and density.
\end{abstract}

\section{Introduction}

Compacting is the process of mechanically densifying a soil by pressing the soil particles together into a close state of contact so that the entrapped air can be expelled from the soil mass [1]. Compacting of earth blocks is usually referred to as tamping. Traditional tamping used wooden tamper to manually press the earth in a wooden mould to form the blocks. Currently, earth blocks are compacted with compressed earth block machines such as advance earth construction technologies (AECT) compressed earth block machines [2], CINVA-RAM press [3], BREPAK block making machine [4], among others. These presses are not expensive as they do not require high energy to operate and their maintenance is not complex [5]. CINVA-RAM press was the first machine developed to compact soil into a high density block in Colombia during 1952 [6].

The idea of compacting earth is to improve the quality and performance of moulded earth blocks [7, 8]. Earth blocks are often compacted to improve their engineering characteristics, and this can be done in three ways: (1) dynamic compaction, (2) static compaction, and (3) vibratory compaction for earth blocks improvement [9]. Compressed earth blocks are generally produced by compacting soil in a hydraulic or electrical block making machine, in which static and control pressure is applied. Houben and Guillaud [10] have made a characterisation of moulding pressure for earth/soil blocks:

(i) Very low: 1-2 MPa

(ii) Low: 2-4 MPa

(iii) Average: 4-6 MPa

(iv) High: 6-10 MPa

(v) Hyper: 10-20 MPa

(vi) Mega: $20-40+\mathrm{MPa}$

Houben et al. [11] provided an overview of machines and their compaction pressures as shown in Table 1. Some of the compaction pressure applied in making earth blocks in previous studies are provided in Table 2.

Since compaction pressure application in producing earth blocks is important to the engineering properties of the blocks, it is also imperative to find out if the rate (speed) of applying the compaction pressure could as well affect the properties of the compressed earth blocks. This study therefore investigates the influence of compacting rate for 
TABLE 1: Commercial compaction machines and pressure.

\begin{tabular}{lc}
\hline Machine & Compaction pressure \\
\hline Altech Geo 50 & $3.5 \mathrm{MPa}$ \\
Appro-Techno Terstaram & $3.6 \mathrm{MPa}+$ impact \\
Ausbildungsverbund AVM CINVA Ram & $2.0 \mathrm{MPa}$ \\
Cartem manual elephant block maker & $10.8 \mathrm{MPa}$ \\
Ceratec ceraram & $2.4 \mathrm{MPa}+$ impact \\
Concrete machinery systems BREPAK & $10.8 \mathrm{MPa}$ \\
Nigerian building and road research & $3.0 \mathrm{MPA}$ \\
NBRRI block making machine & $1-2 \mathrm{MPa}$ \\
Sheltertech block press & $1.1 \mathrm{MPa}$ \\
Societe nouvelle presse a parpaing & $1.2 \mathrm{MPa}$ \\
TTera structure TPM & $2.5 \mathrm{MPa}$ \\
Untata 1003 & $3.7 \mathrm{MPa}$ \\
Urpata 5005 &
\end{tabular}

TABLE 2: Compaction pressure used for making earth blocks in previous studies.

\begin{tabular}{lc}
\hline Reference & Compaction pressure \\
\hline Burroughs [12] & $2.7 \mathrm{MPa}$ \\
Cao et al. [13] & $10 \mathrm{MPa}$ \\
Chan [14] & $10 \mathrm{MPa}$ \\
Danso et al. [15] & $10 \mathrm{MPa}$ \\
Danso et al. [16] & $10 \mathrm{MPa}$ \\
Danso et al. [17] & $10 \mathrm{MPa}$ \\
Gooding and Thomas [18] & $2-10 \mathrm{MPa}$ \\
Millogo et al. [19] & $2 \mathrm{MPa}$ \\
Walker and Stace [20] & $2 \mathrm{MPa}$ \\
Walker [21] & $2-4 \mathrm{MPa}$ \\
Walker [22] & $2 \mathrm{MPa}$ \\
Donkor and Obonyo [23] & $1.6 \mathrm{MPa}$ \\
\hline
\end{tabular}

producing compressed earth blocks on the properties of the blocks. Furthermore, the study seeks to determine the correlation between the tests carried out.

\section{Experimental Method}

2.1. Preparation of Specimen. The main materials used are soil sample and water. Table 3 reports the characteristics of the soil used for the experimental work. The results indicate that the soil is low plasticity clay (CL) soil [24]. The particle size distribution curve of the soil is shown in Figure 1. Chemical element/composition of the soil was determined through inductively coupled plasma-mass spectrometry (ICP-MS) analysis method in accordance with BS EN ISO 17294-1 [25] and the result is also reported in Table 3. The $\mathrm{pH}$ value of 6.67 indicates that the soil is slightly alkaline.

The soil was weighed and spread on platform. Water was added to achieve the optimum moisture content (OMC) of $11.8 \%$ as obtained in Table 3 by sprinkling on the soil and repeatedly turned until a uniform mixture was obtained. The mixture was used to fill a steel cylindrical mould with a top
TABLE 3: Soil characteristics.

\begin{tabular}{|c|c|}
\hline Properties & Value \\
\hline \multicolumn{2}{|l|}{ Atterberg limits } \\
\hline Liquid limit (\%) & 33 \\
\hline Plastic limit (\%) & 25 \\
\hline Plasticity index & 8 \\
\hline \multicolumn{2}{|l|}{ Soil classification } \\
\hline USCS & $\mathrm{CL}$ \\
\hline \multicolumn{2}{|l|}{ Compaction } \\
\hline Maximum dry density $\left(\mathrm{Mg} / \mathrm{m}^{3}\right)$ & 1.83 \\
\hline Optimum moisture content (\%) & 11.8 \\
\hline \multicolumn{2}{|l|}{ Particle size (\%) } \\
\hline Gravel $(>2000 \mu \mathrm{m})$ & 8 \\
\hline Sand $(75-2000 \mu \mathrm{m})$ & 64 \\
\hline Silt $(2-75 \mu \mathrm{m})$ & 16 \\
\hline Clay $(<2 \mu \mathrm{m})$ & 12 \\
\hline \multicolumn{2}{|l|}{ pH } \\
\hline Value & 6.67 \\
\hline \multicolumn{2}{|l|}{ Chemical composition $(m g / L)$} \\
\hline $\mathrm{SiO}_{2}$ & 76.6 \\
\hline $\mathrm{TiO}_{2}$ & 0.97 \\
\hline $\mathrm{Al}_{2} \mathrm{O}_{3}$ & 10.53 \\
\hline $\mathrm{Fe}_{2} \mathrm{O}_{3}$ & 3.24 \\
\hline $\mathrm{MnO}$ & 0.05 \\
\hline $\mathrm{MgO}$ & 1.58 \\
\hline $\mathrm{CaO}$ & 0.37 \\
\hline $\mathrm{Na}_{2} \mathrm{O}$ & 0.73 \\
\hline $\mathrm{K}_{2} \mathrm{O}$ & 2.26 \\
\hline $\mathrm{P}_{2} \mathrm{O}_{5}$ & 0.16 \\
\hline
\end{tabular}

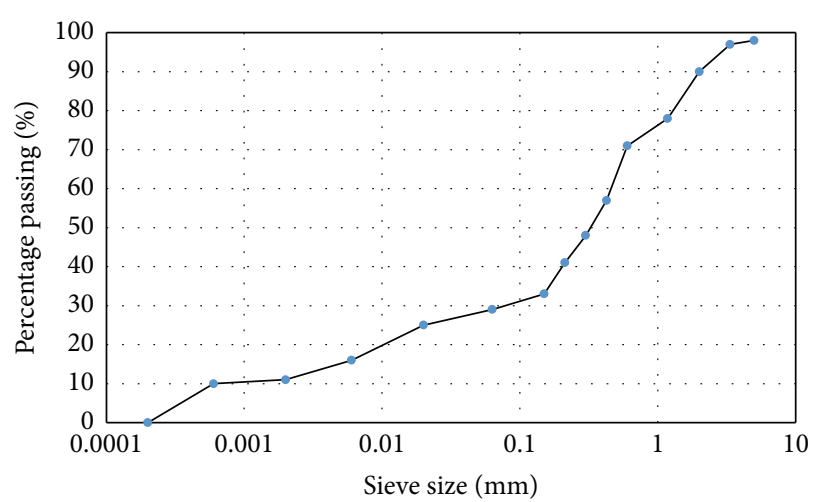

FIgURE 1: Particle size distribution of experimental soil.

piston presser. The mould of $40 \mathrm{~mm}$ internal diameter and $125 \mathrm{~mm}$ length cylinder was filled (in three layers) with soil and compressed to a length of $80 \mathrm{~mm}$ with Tinius Olsen H50KS (Figure 2(a)) obtained as cylindrical specimen of 40 $\times 80 \mathrm{~mm}$. After the soil was pressed to the required shape and size of the specimen, it was then extruded (Figure 2(b)) from the mould by using hand press. The specimens were pressed by the application of four (4) different compacting speed, which are $1 \mathrm{~mm} / \mathrm{min}, 5 \mathrm{~mm} / \mathrm{min}, 10 \mathrm{~mm} / \mathrm{min}$, and 


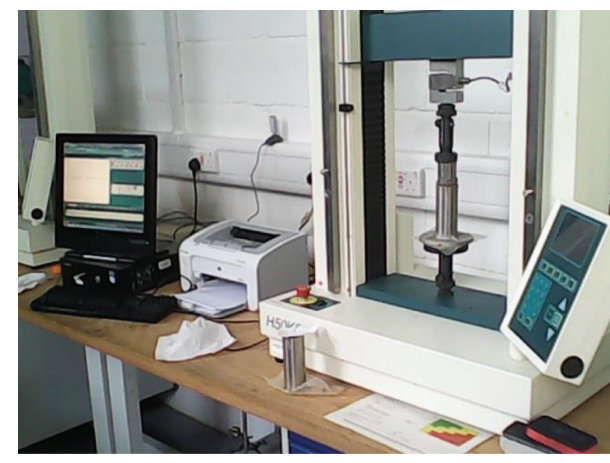

(a)

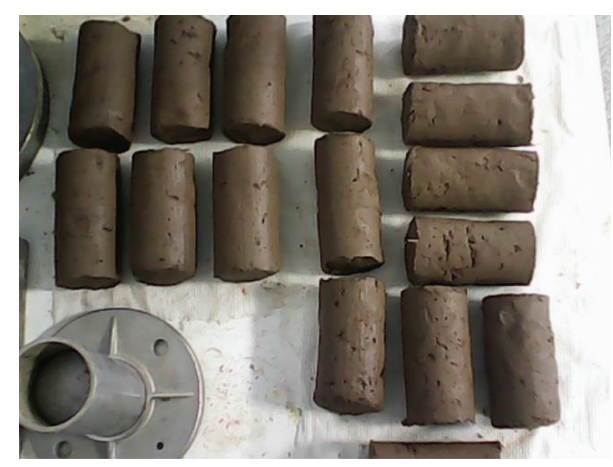

(b)

Figure 2: (a) Specimen under compaction, (b) specimen extruded from mould.

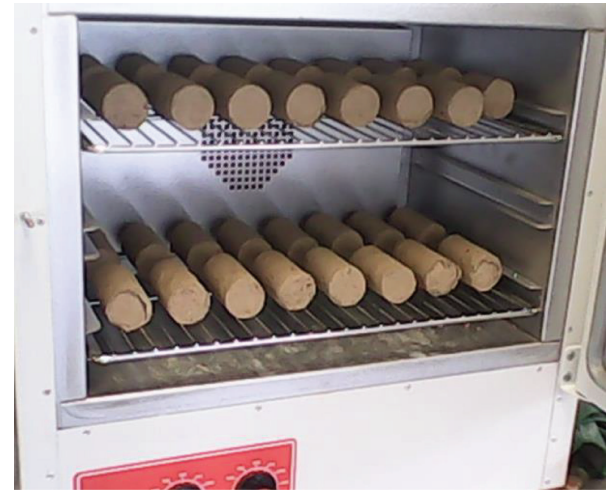

FIGURE 3: Drying specimen in oven.

$15 \mathrm{~mm} / \mathrm{min}$. The specimens were then placed in an oven for drying at $40^{\circ} \mathrm{C}$ (Figure 3 ). After the specimens were dried (when the difference in the successive weights of the cooled sample at interval of $4 \mathrm{hr}$ after $72 \mathrm{hr}$ did not exceed $0.1 \%$ ), they were set for testing. Three specimens were selected for each test type and each compacting speed for testing.

2.2. Testing of Specimen. Four (4) different tests were conducted to determine the influence of compacting rate on compressed earth blocks. The tests include density, compressive strength, tensile strength, and erosion (drip).

2.2.1. Density. Density of the specimen was determined in accordance with British Standard Institute BS EN 772:11 [26]. The specimens were dried at constant temperature of approximately $110^{\circ} \mathrm{C}$ in an oven for $48 \mathrm{hr}$ until consistent mass was obtained. The dimensions of each specimen were measured and the overall volume computed. The specimens were then weighed and the density was calculated from

$$
\rho=\frac{m}{V}
$$

where $\rho$ is the density $\left(\mathrm{kg} / \mathrm{m}^{3}\right) ; m$ is the mass $(\mathrm{kg})$; and $V$ is the volume $\left(\mathrm{m}^{3}\right)$.
2.2.2. Compressive Strength. Compressive strength test was conducted in accordance with British Standard Institute BS EN 772:11 [26]. The test was made with Tinius Olsen H50KS for which three specimens were tested for each rate of pressure application. Each specimen was placed uprightly on the base plate of the testing machine and carefully centred (Figure 4(a)). The load was applied on the specimen until it failed (Figure 4(b)). The maximum load at which the specimen failed was recorded and the compressive strength was determined by

$$
f_{c}=\frac{F}{A}
$$

where $f_{c}$ is the compressive strength $(\mathrm{MPa}), F$ is the applied load at which the block failed (N), and $A$ is the surface area of the block where the load was applied $\left(\mathrm{mm}^{2}\right)$.

2.2.3. Splitting Tensile Strength. Splitting tensile strength test was conducted following the principles of British Standard Institute BS EN 12390:6 [27]. Each specimen was placed centrally in the test jig (Figure 5(a)) of the Tinius Olsen H50KS, for which the load was applied till the specimen failed (Figure 5(b)). The maximum load at which the specimen failed was recorded and the tensile strength was determined by

$$
f_{t}=\frac{2 P}{\pi L d}
$$

where $f_{t}$ is the indirect tensile strength $(\mathrm{MPa}) ; P$ is the maximum load sustained by the specimen $(\mathrm{N})$; $d$ is the diameter of the specimen $(\mathrm{mm})$; and $L$ is the length of the specimen $(\mathrm{mm})$.

2.2.4. Drip Test (Geelong Method). Drip test was conducted to determine the erodability (durability) of the specimen. Due to the susceptibility of soil blocks, this test aims at determining the rate at which the soil blocks will erode when exposed to water (rain). The test was conducted in accordance with New Zealand Standard [28]. The equipment was setup with container containing water for which $100 \mathrm{~mL}$ mark from the top was noted. Wettex (J-Cloth) $16 \mathrm{~mm}$ wide was placed 


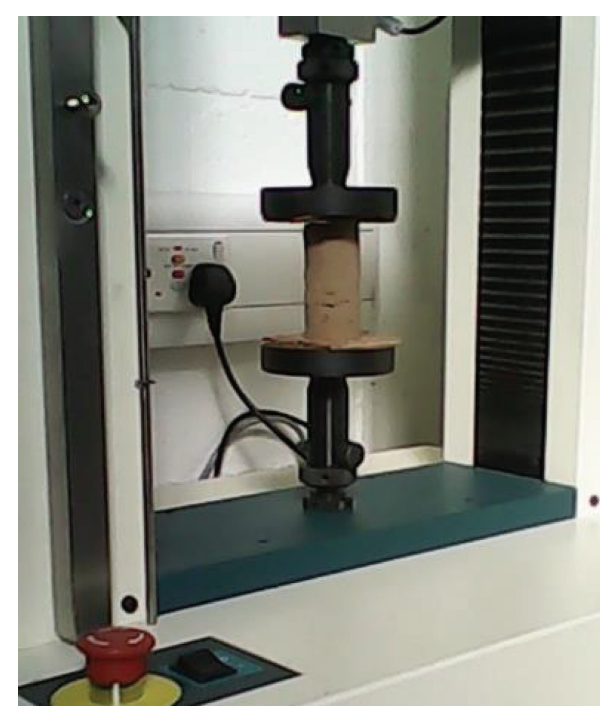

(a)

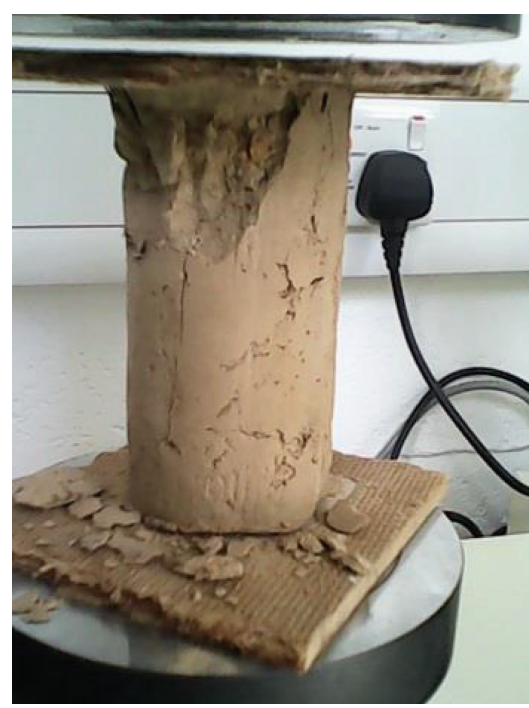

(b)

FIGURE 4: (a) Specimen under compressive stress, (b) failed specimen.

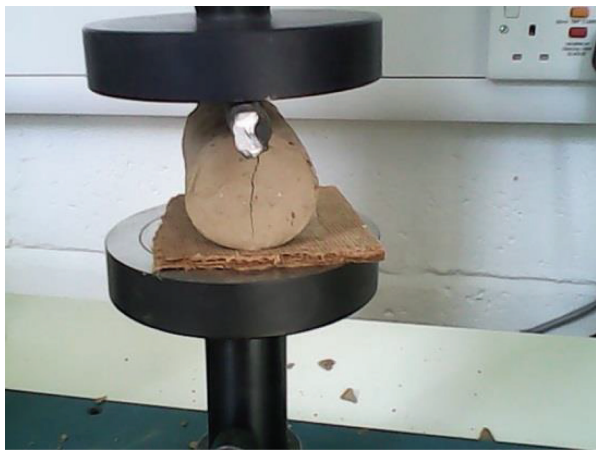

(a)

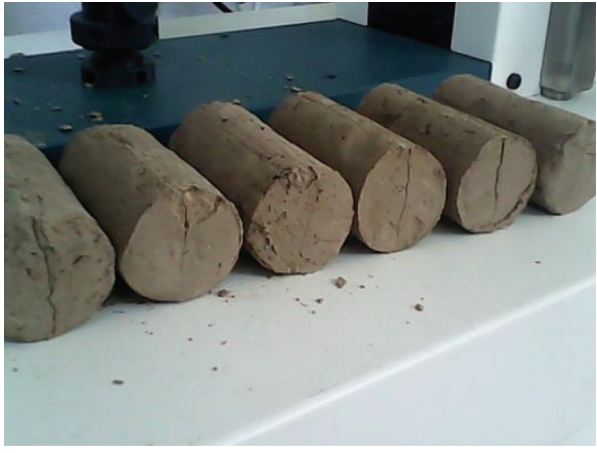

(b)

FIgURE 5: (a) Specimen under tensile stress, (b) failed specimen.

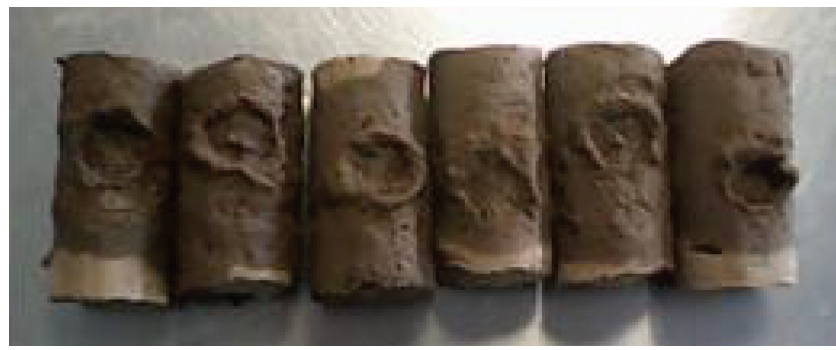

FIGURE 6: Drip test specimen showing depth of pit.

on the container to soak and transmit the water onto the specimen. The specimens were placed at an angle of $27^{\circ}$ at the base and $400 \mathrm{~mm}$ vertically away from the J-Cloth, from which water was allowed to drop on the specimen for one hour. Figure 6 shows the depth of the pit created on the specimen. The pit was then measured and the erodability index was determined.
2.3. Statistical Analysis. Correlations were carried out to establish relationships between the tests performed. The mean results were used and ranges were noted. One-Way ANOVA test result at $95 \%$ confidence interval with Minitab Version 16 was used to test for significant difference and variation between the test types.

\section{Results and Discussion}

3.1. Dry Density. The dry density test results as summarised in Figure 7 show a closely related average density among the different compacting rates, between $1866 \mathrm{~kg} / \mathrm{m}^{3}$ and $1894 \mathrm{~kg} / \mathrm{m}^{3}$. Similar result was obtained in the study by Chan [14], where the nonbaked specimens did not undergo obvious density change. This was expected due to the equal mass of the mix used for producing each test specimen. However, there was slight reduction in density within $5-15 \mathrm{~mm} / \mathrm{min}$ compaction rates. The density is the relationship between the volume and the mass of the blocks and therefore shows 


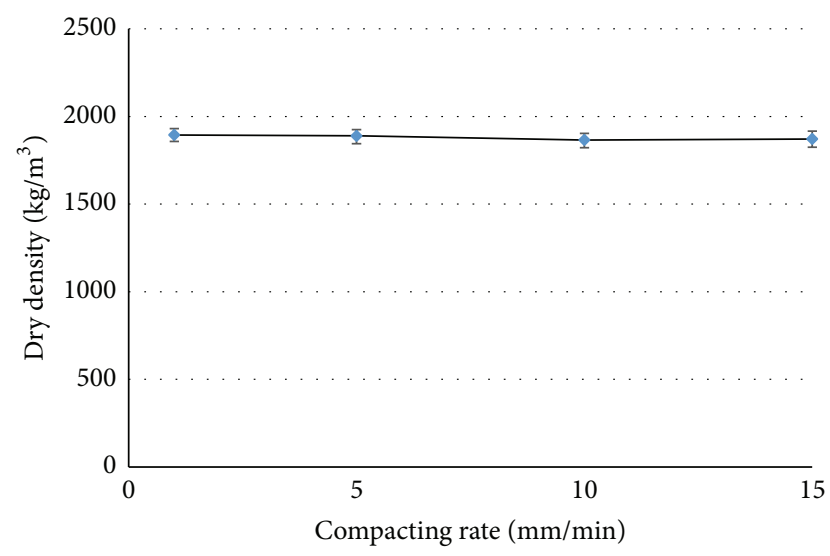

FIgURE 7: Dry density of compressed earth blocks (error bars represent range of data obtained).

how compact the blocks are [29]. The dry density is largely a function of the constituent material characteristics, such as moisture content at pressing and the degree of compaction effort applied [21]. This implies that the compacting rates may have some influence on the density of the blocks. Although there was slight difference in the density among the compacting rates, the result indicates that the lower rates (1 and $5 \mathrm{~mm} / \mathrm{min}$ ) of compaction achieved the highest density. This implies that the slower the application of compacting load the better the arrangement of the material constituents, making the block slightly denser. The percentage variation between the 1 and $15 \mathrm{~mm} / \mathrm{min}$ compaction rates is $<1 \%$. To check if the difference in the test results is significant or not, One-Way ANOVA test was conducted.

ANOVA test result at 95\% confidence interval indicates that the differences in the values among the different compacting rates are insignificant to exclude the possibility that the difference is due to random sampling variability. There is therefore not a statistically significant difference $(p=0.799$; $F=0.340)$ in dry density among the compacting rates of the compressed earth blocks.

3.2. Compressive Strength. Figure 8 presents the summary of the compressive strength test result. The result indicates that the average compressive strength decreased with increase in compacting rates, implying that the higher the compacting rate the lower the compressive strength of the blocks. The reduction could be attributed to the reduced density of the blocks as the compacting rate increases. There was about 19\% increase in the average compressive strength of the lower $(1 \mathrm{~mm} / \mathrm{min})$ compacting rate over the higher $(15 \mathrm{~mm} / \mathrm{min})$ compacting rate.

ANOVA test result indicates that the differences in the values among the different compacting rates are insignificant to exclude the possibility that the difference is due to random sampling variability. There is therefore not a statistically significant difference ( $p=0.410 ; F=1.010)$ in compressive strength among the compacting rates of the soil blocks.

The correlation between the compressive strength and the density of the compressed earth blocks is summarised

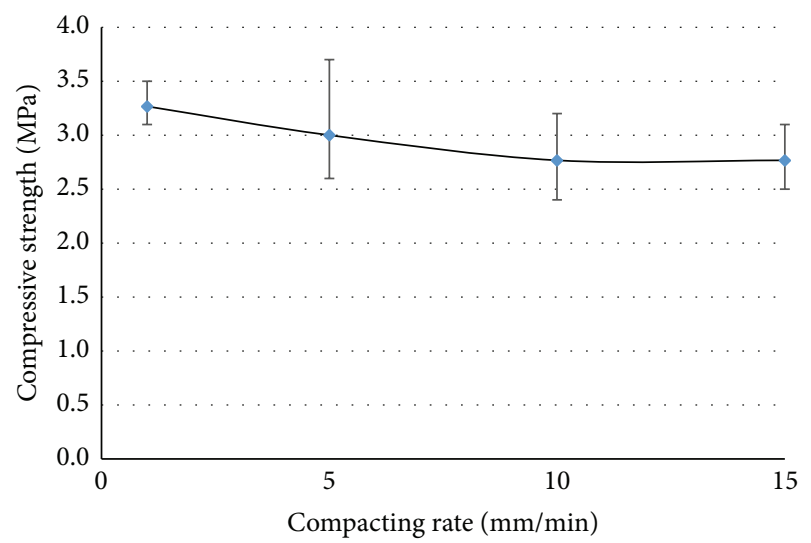

FIGURE 8: Compressive strength of compressed earth blocks (error bars represent range of data obtained).

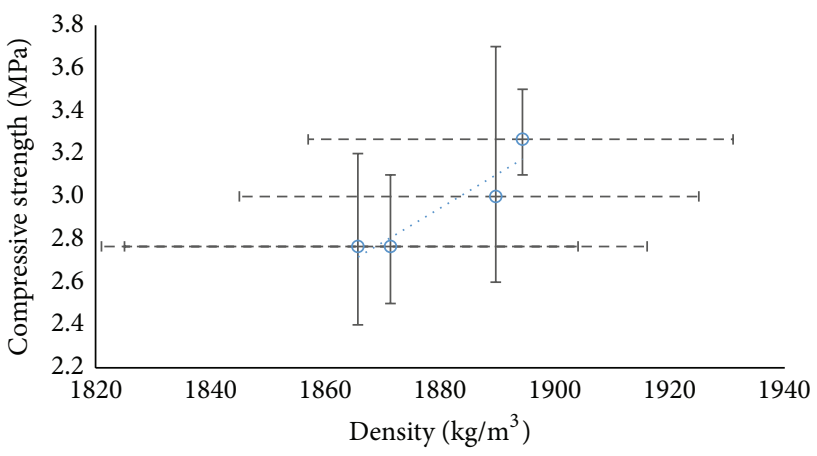

FIGURE 9: Correlation between compressive strength and density.

in Figure 9. The result indicates a strong linear correlation between the compressive strength and the density with coefficient of determinant $\left(R^{2}\right)$ of 0.867 , though these are based on the means of scattered data. This aligns with Gooding and Thomas [18] and Walker [21] observation that a given increase in density will result in a greater increase in strength.

3.3. Splitting Tensile Strength. The summary of the splitting tensile strength test result is presented in Figure 10. The result is similar to the compressive strength; however, the $10 \mathrm{~mm} / \mathrm{min}$ speed recorded an increase in tensile strength compared to both 5 and $15 \mathrm{~mm} / \mathrm{min}$ compacting rates. The lower compacting rate recorded the highest strength while the highest compaction recorded the lowest as in the case of compressive strength. This suggests that the lower compacting rate application makes the soil particles arrange to eliminate bigger pores in the soil matrix, which contributes to the increased resistance of the material against splitting failure.

There was about $20 \%$ average tensile strength increase of the lower compacting rate over the higher compacting rate, which was similar to the compressive strength result. The ANOVA test result indicates that there is not a statistical significant difference ( $p=0.596 ; F=0.670$ ) between the compacting rates of the soil blocks. 


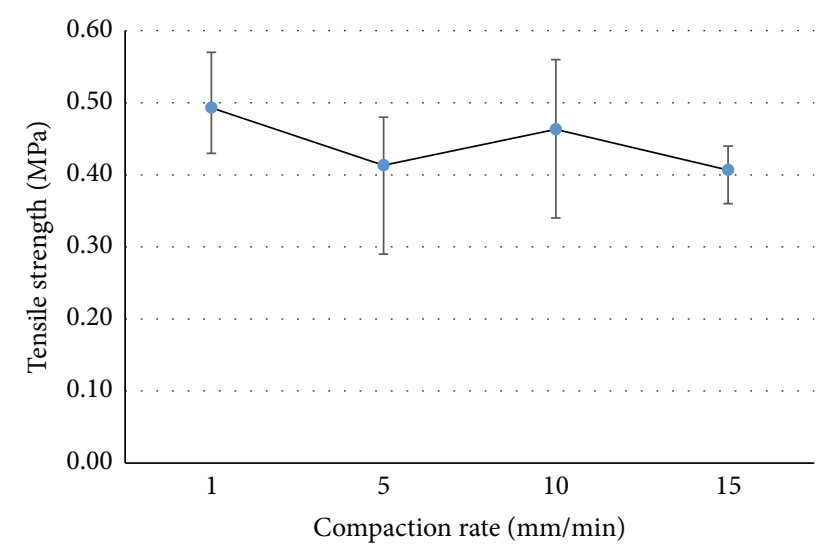

FIGURE 10: Tensile strength of compressed earth blocks (error bars represent range of data obtained).

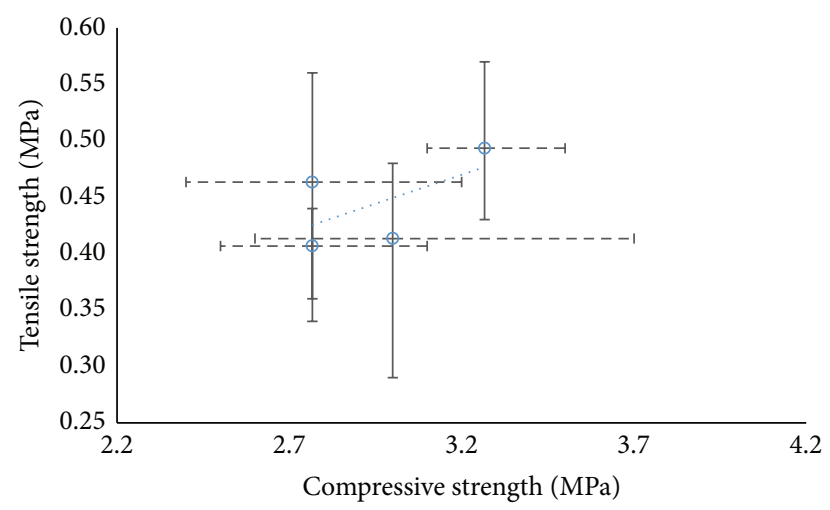

FIGURE 11: Correlation between tensile and compressive strengths.

The correlation between tensile strength and compressive strength, and tensile strength and density of the soil blocks can be found in Figures 11 and 12, respectively. The results indicate a weak linear correlation between tensile strength and compressive strength, and tensile strength and density with coefficient of determinant $\left(R^{2}\right)$ of 0.346 and 0.070 , respectively, though these are based on the means of scattered data.

3.4. Erosion Test. A summary of the drip test result is provided in Table 4 . It can clearly be seen from the result that the depth of pit increased with the increase in compaction rates. This shows some similarities in the result of the density test, where density of the blocks reduced with increased compacting rates. This suggests that densification of the blocks may affect the rate of the erosion of the soil blocks. The low rate of compaction increased slightly the density of the soil blocks and therefore may have reduced the erodability rate. This means that the lower the compacting rate of producing compressed earth blocks, the lower the effect of erosion by rain or water on the blocks.

The result shows that the depth of pit for all the compacting rates was within erodability index of 3 , which means they were all erosive [28]. However, the low compacting rate

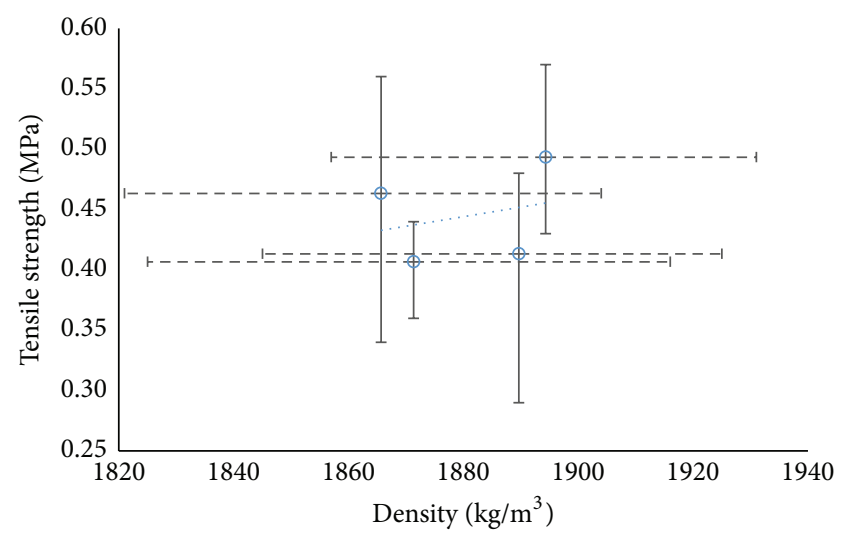

FIGURE 12: Correlation between tensile strength and density.

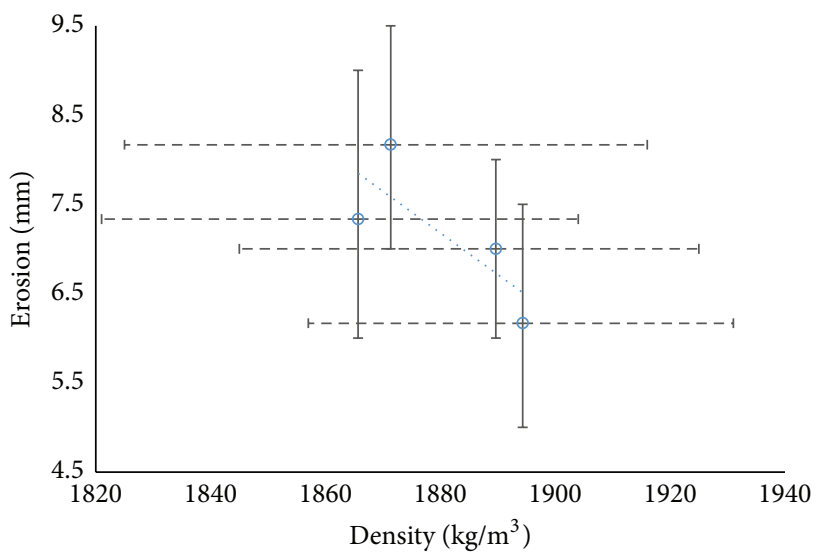

FIGURE 13: Correlation between erosion and density.

performance was better than the higher rates. The percentage variation between the 1 and $15 \mathrm{~mm} / \mathrm{min}$ compaction rates is $>7 \%$. Conversely, the test of significant difference indicates that there is not a statistically significant difference $(p=$ $0.458 ; F=1.26$ ) among the compacting rates of the specimens.

Figures 13 and 14 show the correlation between erosion and density, and erosion and tensile strength, respectively, of the soil blocks. The results indicate good linear relationship between tensile strength and density, and tensile strength and compressive strength with coefficient of determinant $\left(R^{2}\right)$ of 0.612 and 0.831 , respectively, though these are based on the means of scattered data.

\section{Conclusion}

The investigation concludes that although the lower rate of compaction achieved slightly better performance characteristics, there was not a statistically significant difference between the compressed earth blocks produced with low compacting rate and high compacting rate. This means the rate of compacting the compressed earth blocks during the production does not have significant effect on the properties of the blocks. This study has demonstrated that there is not much influence on the properties of compressed earth blocks 
TABLE 4: Drip test results.

\begin{tabular}{lccc}
\hline Compaction rate $(\mathrm{mm} / \mathrm{min})$ & Average depth of pit $(\mathrm{mm})$ & Erodability index $\left(E_{I}\right)$ & Rating \\
\hline 1 & 6.2 & 3 & Erosive \\
5 & 7.0 & 3 & Erosive \\
10 & 7.3 & 3 & Erosive \\
15 & 8.2 & Erosive \\
\hline
\end{tabular}

$E_{I} 1=0$ (nonerosive), $E_{I} 2=0<5$ (slightly erosive), $E_{I} 3=>5 \leq 10$ (erosive), and $E_{I} 4=>10$ (very erosive).

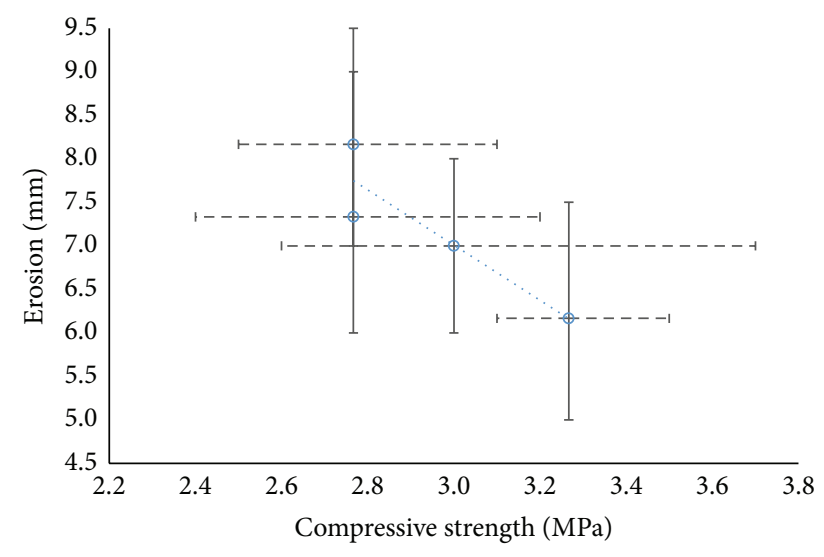

FIGURE 14: Correlation between erosion and compressive strength.

produced with low and high compacting rates. Furthermore, there were positive linear correlations between the tests carried out. Thus, the compressive strength test result could be associated with the density test result of the blocks. Similarly, there was a common trend in the test results of the density and the erosion. However, there was a weak linear correlation between tensile strength and compressive strength, and tensile strength and density.

\section{Competing Interests}

The author declares that they have no competing interests.

\section{References}

[1] FM 5-410, "Military soils engineering," in Soil compaction, Field Manual 5-410, Washington, DC, USA, 1992, http://www.bits.de/ NRANEU/others/amd-us-archive/fm5_410(97).pdf.

[2] AECT, AECT Compressed Earth Block. Advanced Earthen Construction Technologies, 2009, http://www.aectceb.com.

[3] C. Taylor, Cinva Ram Compressed Earth Block Press Plans, 2011, http://www.dirtcheapbuilder.com/Home_Building/Earth_Block_ Construction.htm.

[4] D. T. J. Webb, Stabilised soil building blocks [Ph.D. thesis], University of Newcastle, Newcastle, UK, 1988, https://theses.ncl.ac .uk/dspace/handle/10443/283.

[5] Y. K. A. Al-Sakkaf, Durability properties of stabilized earth blocks [Ph.D. thesis], Universiti Sains Malaysia, 2009.

[6] B. V. Venkatarama Reddy and A. Gupta, "Characteristics of soil-cement blocks using highly sandy soils," Materials and Structures, vol. 38, no. 280, pp. 651-658, 2005.
[7] H. Guillaud, P. Odul, and T. Joffroy, Manual of Design and Construction, vol. 2, Friedrich Vieweg \& Sohn Verlagsgesellscahft mbH, Wiesbaden, Germany, 1995.

[8] H. Danso, B. Martinson, M. Ali, and C. Mant, "Performance characteristics of enhanced soil blocks: a quantitative review," Building Research \& Information, vol. 43, no. 2, pp. 253-262, 2015.

[9] B. V. Venkatarama Reddy and K. S. Jagadish, "The static compaction of soils," Geotechnique, vol. 43, no. 2, pp. 337-341, 1993.

[10] H. Houben and H. Guillaud, Earth Construction: A Comprehensive Guide, Intermediate Technology Publications, London, UK, 1994.

[11] H. Houben, V. Rigassi, and P. Garnier, Eds., Compressed Earth Blocks: Production Equipment, Technologies (CDI) 5, CDI \& CRETerre-EAG, Brussels, Belglum, 1996.

[12] S. Burroughs, "Strength of compacted earth: linking soil properties to stabilizers," Building Research \& Information, vol. 34, no. 1, pp. 55-65, 2006.

[13] Y. Cao, S. Shibata, and I. Fukumoto, "Mechanical properties of biodegradable composites reinforced with bagasse fibre before and after alkali treatments," Composites Part A: Applied Science and Manufacturing, vol. 37, no. 3, pp. 423-429, 2006.

[14] C. M. Chan, "Effect of natural fibers inclusion in clay bricks: physico-mechanical properties," International Journal of Civil and Environmental Engineering, vol. 3, pp. 51-57, 2011.

[15] H. Danso, D. B. Martinson, M. Ali, and J. B. Williams, "Physical, mechanical and durability properties of soil building blocks reinforced with natural fibres," Construction and Building Materials, vol. 101, pp. 797-809, 2015.

[16] H. Danso, D. B. Martinson, M. Ali, and J. Williams, "Effect of fibre aspect ratio on mechanical properties of soil building blocks," Construction and Building Materials, vol. 83, pp. 314319, 2015

[17] H. Danso, D. B. Martinson, M. Ali, and J. Williams, "Effect of sugarcane bagasse fibre on the strength properties of soil blocks," in Proceedings of the 1st International Conference on BioBased Building Materials, Clermont-Ferrand, France, June 2015.

[18] D. Gooding and T. Thomas, "Soilcrete blocks," Building Research \& Information, vol. 25, no. 4, pp. 202-209, 1997.

[19] Y. Millogo, J.-C. Morel, J.-E. Aubert, and K. Ghavami, “Experimental analysis of Pressed Adobe Blocks reinforced with Hibiscus cannabinus fibers," Construction and Building Materials, vol. 52, pp. 71-78, 2014.

[20] P. Walker and T. Stace, "Properties of some cement stabilised compressed earth blocks and mortars," Materials and Structures, vol. 30, no. 203, pp. 545-551, 1997.

[21] P. J. Walker, "Strength, durability and shrinkage characteristics of cement stabilised soil blocks," Cement \& Concrete Composites, vol. 17, no. 4, pp. 301-310, 1995. 
[22] P. J. Walker, "Strength and erosion characteristics of earth blocks and earth block masonry," Journal of Materials in Civil Engineering, vol. 16, no. 5, pp. 497-506, 2004.

[23] P. Donkor and E. Obonyo, "Compressed soil blocks: influence of fibers on flexural properties and failure mechanism," Construction and Building Materials, vol. 121, pp. 25-33, 2016.

[24] British Standard Institute BS 5930, "Code of practice for ground investigations," 2015, https://bsol.bsigroup.com.

[25] B. S. I. B. E. I. 17294:1, "Water quality. Application of inductively coupled plasma mass spectrometry (ICP-MS)," 2006, https://bsol.bsigroup.com.

[26] British Standard Institute BS EN 772:11, "Methods of test for masonry units," 2011, https://bsol.bsigroup.com.

[27] British Standard Institute BS EN 12390:6, "Testing hardened concrete. Tensile splitting strength of test specimens," 2009, https://bsol.bsigroup.com.

[28] Standard New Zealand, "Materials and workmanship for earth buildings," New Zealand Standard NZS 4298, Standard New Zealand, Wellington, New Zealand, 1998.

[29] H. Danso, Use of agricultural waste fibres as enhancement of soil blocks for low-cost housing in Ghana [Ph.D. thesis], School of Civil Engineering and Surveying, University of Portsmouth, 2015, http://eprints.port.ac.uk/id/eprint/20762. 

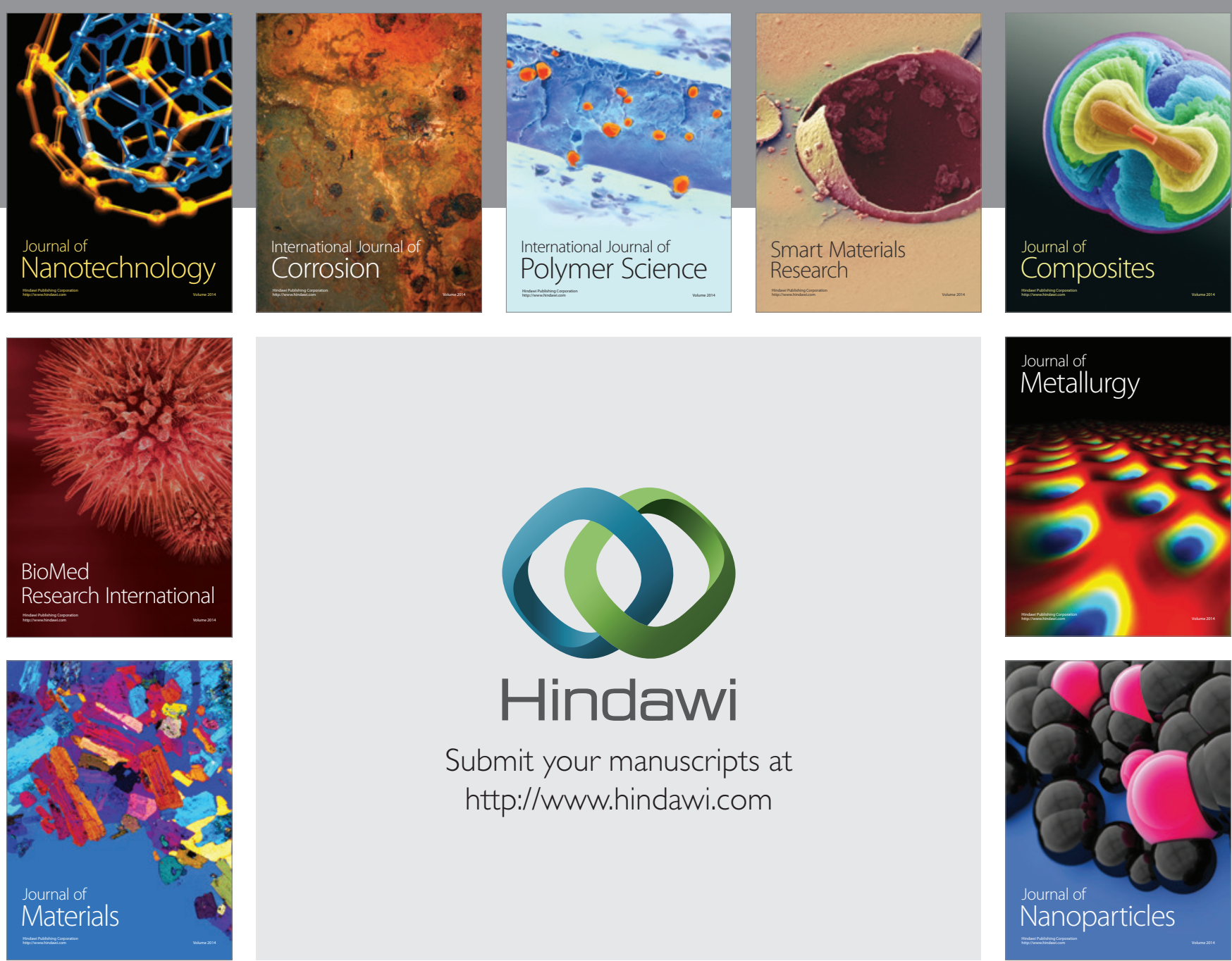

\section{Hindawi}

Submit your manuscripts at

http://www.hindawi.com

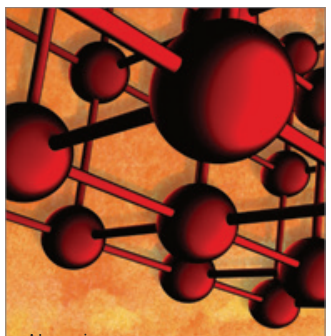

Materials Science and Engineering
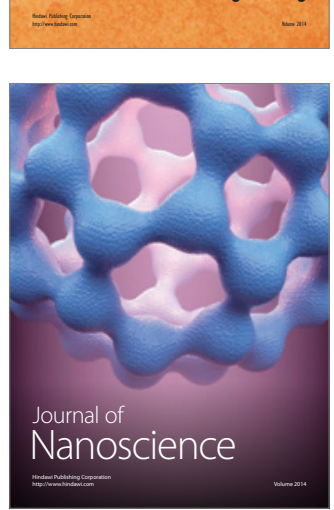
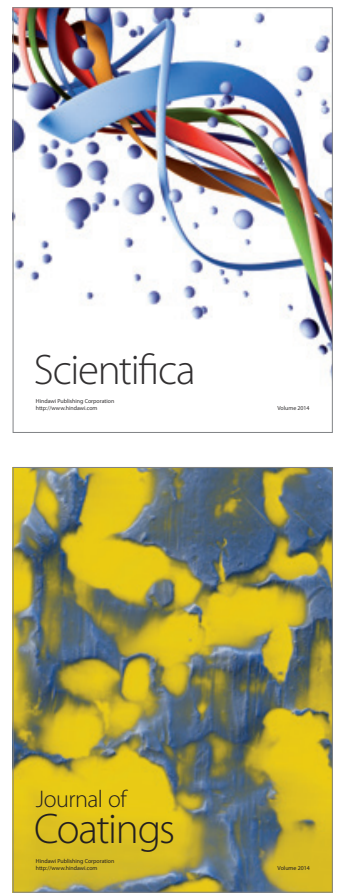
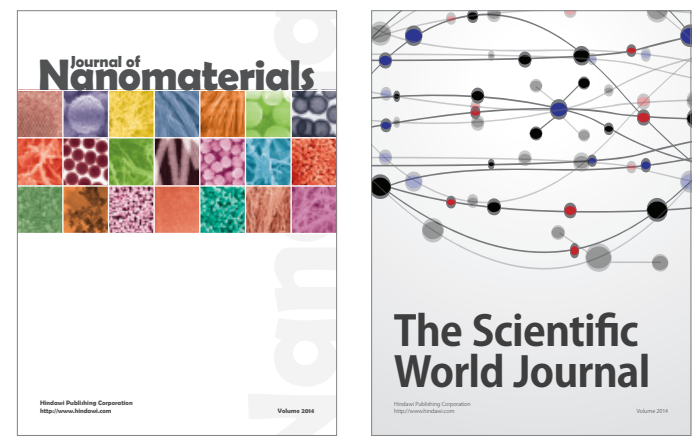

The Scientific World Journal
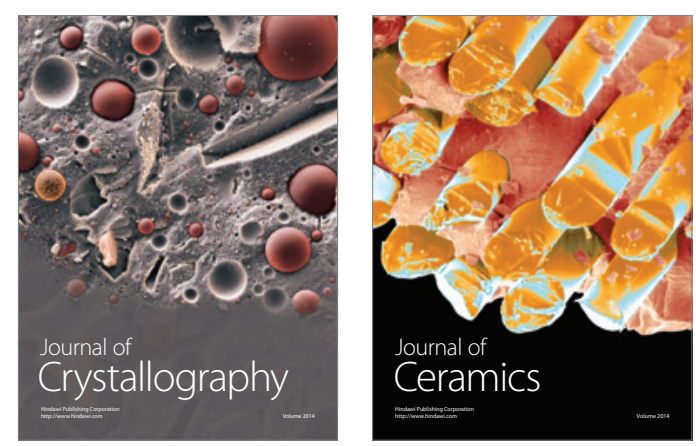
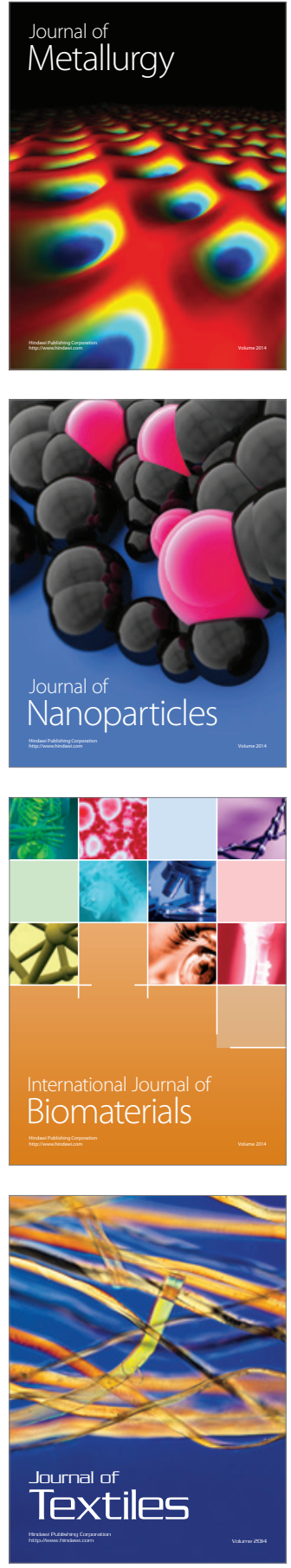